\title{
A noção de ação a partir dos modelos representacionais de Artur Barrio e Tadeusz Kantor
}

Merle Ivone Barriga *

Neste texto propomos abordar o conceito de ação, elemento fundamental da cena; e nos centraremos em manifestações singulares do século XX. Dentro de uma cena atual que apresenta variados desdobramentos, a noção de ação é ampla e flexível, não se limitando a conformar a trama de eventos concatenada a partir da lógica causal. Este conceito mais amplo de ação (que incopora o acaso e certa irracionalidade) não se opõe à ação aristotélica - modelo estético que guarda em si parte importante da história do conhecimento humano -, mas questiona a ação pragmática e hegemônica da indústria cultural e da sociedade de consumo. Apresentaremos a seguir alguns apontamentos sobre características observadas no pensamento/obra de Artur Barrio e Tadeusz Kantor, que definiriam modelos de ação muito particulares na obra de cada um destes artistas. $\mathrm{O}$ objetivo deste ensaio é provocar uma reflexão sobre formas atuais e nem sempre evidentes da ação cênica, seja dentro de um modelo teatral mais difundido (formas teatrais associadas à idéia de espetáculo), seja sob a forma de eventos deliberadamente ambíguos na sua forma de apresentação.

Tadeusz Kantor (1915-1990) e Artur Barrio (1945- ) apresentam em comum o fato de serem artistas plásticos que, através de determinadas estratégias criativas de valorização da materialidade, se aproximaram do fato cênico - se lembrarmos que, dentro das artes plásticas, a passagem da obra do domínio da imagem para o terreno da experiência desemboca en obras híbridas -, produzindo trabalhos altamente singulares dentro da cena contemporânea. ${ }^{1}$

Ao contrapor ambos artistas somos cientes da distancia histórica, espacial e estética que os separa, esta conexão é feita a posteriori e guiada sobretudo pelo nosso interesse em estudar a ação como ponto de síntese e encontro entre criadores das chamadas artes de fronteira. ${ }^{2}$

Também salientamos o nosso desejo em difundir uma parte do instigante trabalho de Artur Barrio, artista atualmente em atividade no Brasil e infelizmente ainda pouco conhecido por pesquisadores do nosso meio. Por outra parte, a análise sobre duas formas de lidar com a noção de representação visa provocar uma reflexão sobre as possibilidades latentes da cena contemporânea.

Artur Barrio ${ }^{3}$ ganhou cedo certo reconhecimento não apenas por enveredar para um caminho próximo da performance com as ações, ${ }^{4}$ mas por desenvolver um trabalho informe e anti-estético a partir da utilização de elementos orgânicos e de rápida decomposição. O trabalho de ações de Barrio também apresentou a particularidade de não considerar relevante a noção de público - embora deixasse aos acidentais pedestres liberdade integral para lidar com trabalhos cujo controle, uma vez lançados nas ruas, fugia completamente do

\footnotetext{
* Diretora de teatro e pesquisadora teatral, mestre em artes cênicas pela Escola de Comunicações e Artes da Universidade de São Paulo ao defender a dissertação "As Ações de Artur Barrio: Um modelo não representacional para o ator contemporâneo”. Contato:mivonebspain@yahoo.com
} 
artista -, assim como de se distanciar radicalmente da idéia mais difundida de espetáculo (seja na performance ou na montagem teatral), na realização de projetos que lidavam com aspectos mais indiciais e imanentes no seu diálogo com a realidade. A seguir, analizaremos com maior detenimento as características mencionadas e passaremos a relacioná-las com um pensamento que se posicionou criticamente em face a um mercado de arte condicionado à cultura de consumo.

\section{A ação como negação do espetáculo}

Com relação ao primeiro aspecto apontado - a maneira com que o artista lidou com os materiais usados - observamos duas questões. A primeira diz respeito do tipo de material escolhido pelo artista para realizar as suas ações: materiais baratos, de uso corrente e de natureza orgânica. Esta escolha não nos parece arbitrária, uma vez que Barrio explicitou com bastante clareza as motivações do seu projeto artístico:

"Devido a uma série de situações no setor artes plásticas, no sentido do uso cada vez maior de materiais considerados caros, para a nossa, minha realidade, num aspecto socio-econômico do $3^{\circ}$ mundo (América Latina, inclusive) devido aos produtos industrializados não estarem ao nosso, meu, alcance, mas sob o poder de uma elite que contesto, pois a criação não pode estar condicionada, tem de ser livre (...) lanço em confronto situações momentâneas com o uso de materiais perecíveis, num conceito de baixo para cima."

$\mathrm{O}$ artista se recusou a entender o trabalho artístico como dependente de materiais caros e fora do seu alcance econômico para realização da obra. O gesto singelo de rejeitar o uso de materiais de alto custo e optar por trabalhar com elementos de fácil acesso expressa uma preocupação em discutir processualmente uma questão fundamental do fazer artístico e que leva embutida uma visão crítica da tradicional noção de belo. Por outro lado, a condição póstuma de um trabalho realizado com materiais orgânicos questiona a transcendência da obra de arte, já que estes estão fadados, na sua gênese, ao desaparecimento - Quem pode ver a obra e em que condições isso é possível? O que resta da obra? O registro fotográfico, o depoimento das testemunhas, o registro textual e imagético feito pelo artista e compilado nos seus CadernosLivros? O que pode ser vendido ou comprado no mercado da arte, quando o trabalho em si desaparece? A escolha por trabalhar com ossos, escarro ou pão fala também de uma realidade pulsante e que se mostra deliberadamente desregrada na sujeira e desordem manifestos - parece-nos uma pulsão de vida cujo "efeito realista" ${ }^{6}$ mostra eficácia no questionamento que levanta sobre o papel da arte dentro de uma economia de mercado. A opção de Barrio ao escolher lidar com estes materiais concretiza um pensamento orgânico que propõe a superação de binomios e opostos que se encontram e dialogam a partir de uma particular (des)ordem que (des)organiza a sua poética: 


\begin{abstract}
"Meu trabalho está ligado a uma situação subjetiva/objetiva -- mente/ corpo.-, considero esta relação uma coisa só, pois é ela que inicia o processo energético que irá deflagrar situações psicorgânicas de envolvimento do espectador, levando-o a uma maior participação em relação à proposta apresentada, seja em seus aspectos tácteis, olfativos, gustativos, visuais, auditivos, seja em suas implicações de prazer ou repulsa...” 7
\end{abstract}

Outro aspecto que o trabalho levanta - sobretudo para nós, artistas e investigadores das artes cênicas -, é a que diz respeito da expressa recusa do artista em se colocar no primeiro plano, já que o foco é deixado precisamente aos materiais lançados no ambiente urbano. Nao é a presença do artista nem a sua atuação que são colocados no centro da obra, ao contrário; o elemento menos enfatizado no desenvolvimento das ações é a figura de Barrio, colocando-se assim na contra-mão da maioria de performances que privilegia a figura do performer. A ausência de expressividade observada no artista o distancia do performer e o aproxima da figura do contra-regra. Nesse sentido, apontamos uma contribuição das ações ao trabalho do ator; elas questionam silenciosamente o conceito de "presença": As metáforas vitalistas utilizadas para falar de, por exemplo, um corpo dilatado, ilustram a procura por um estado corporal "extra-cotidiano", muito valorizado em grande parte da tradição teatral ocidental contemporânea. Já o trabalho de Barrio propõe uma presença não ostensiva do artista, atitude em que observamos talvez as maiores diferenças entre o seu trabalho e a estratégia de choque e escândalo utilizada pelas vanguardas históricas.

O gesto do artista ao se atribuir um papel próximo ao de um contra-regra resulta num trabalho que, ao se centrar na ação de materiais precários e de valor corrente, ${ }^{8}$ mostra uma condição especial: a não espectacularização destas situações. As ações do artista diriam muito mais respeito dos materiais utilizados e do destino que estes tomam - uma vez que o artista os lançava nas ruas, estes ganhavam vida própria - do que da presença do artista, uma presença cuja "espontaneidade" teria a ver com o gesto que, uma vez feito, nunca mais se repete: ${ }^{9}$ a efemeridade exacerbada na proposição de um trabalho minimamente espetacular. Barrio não queria mais nada a não ser a fugacidade do momento, através de ações realizadas em condições precárias e com materiais perecíveis, eis a relação de imanência que o artista português estabeleceu com a experiência cotidiana. Este "grau zero" de representação revela o principal objetivo do artista: desenfatizar a condição de exposição que a priori as ações possuiriam. Eis o paradoxo de trabalhos criados com o intuito de soterrar e confundir uma origem e características intrínsicamente artísticas.

Uma última consideração à respeito do artista e do seu corpo "em cena”. A pesar de termos apontado a intenção de desenfatizar a sua figura - por meio de uma inexpressividade intencional-, é pertinente observarmos que o corpo de Barrio não mostra uma pureza ou neutralidade ideiais: ao contrário, há nele rastos de uma relação lúdica (o procedimento de livre associação usado no percurso realizado pelo artista na ação 4 Dias 4 Noites, em que o artista caminhou ininterruptamente durante 4 dias por ruas de Rio de Janeiro) ou erótica, nos movimentos de um corpo que resgata pulsões primitivas e desregradas no diálogo, seja com a cidade ${ }^{10}$ ou com os materiais. Um corpo que, ao ampliar os seus limites, funde-se com 
a psique e se movimenta por diversos espaços e fluxos, mas não nas zonas já constituidas ou sedimentadas. Trata-se de um corpo que amplia os seus espaços no trânsito que faz entre exterior e interior: um corpo que é suporte e também objeto do trabalho:

"De alguma forma, quando se fala da corporalidade de Barrio, tratase quase sempre de um corpo maior, de ampliação de limites, seja no trabalho processo de 4 Dias 4 Noites (1970), verdadeiro roteiro de captação de sinais e conversão do corpo em mente, ou P...H...(1969), em que o corpo é ponto de apoio auxiliar para um diálogo com o vento, a água e a cidade, através do uso de rolos de papel higiênico - verdadeiros fios de Ariadne -, como elemento criador de formas transitivas, só recolhidas por fotografias . Ou como em experiências posteriores, como Minha cabeça está vazia, Meus olhos olhos estão cheios (1983/1984), que já enuncia no título como os pontos do espaço são enunciados." 11

Por último, o fato de Barrio ter desenfatizado o seu próprio papel dentro das ações não diminui o valor do corpo como parte fundamental do trabalho, mas dá a este uma outra dimensão. A esse respeito, podemos associar a seguinte afirmação de Barrio à idéia de imanência (o baixo), como contraponto ao conceito de transcendência (o cima):

“(...) lanço em confronto situações momentâneas com o uso de materiais perecíveis num conceito de baixo para cima"

Rio de Janeiro - 1969

Podemos interpretar o conceito "de baixo para cima”, pra além de uma evidente alusão a questões político/econômicas, também como forma de aprendeer o corpo, um corpo muitas vezes oculto e submetido a condicionamentos sociais. Qual é o lugar que o corpo passaria a ocupar dentro de um conceito de trabalho "de baixo para cima"? Esse lugar estaria mais próximo das pulsões primitivas do ser humano, libertas de condicionamentos de classe, ligados à moral e aos bons modos que regem não só o comportamento social mas também grande parte das práticas artísticas.

Também como parte da mesma tática de trabalho - denominada aqui de negação do espetáculo-, Barrio questionou uma noção sedimentada de público: as ações eram simplesmente lançadas ao fluxo da realidade cotidiana, num movimento que confundia e embaralhava propositalmente as categorias de arte e vida. ${ }^{12} \mathrm{O}$ conceito de público resultava fora de lugar uma vez que as ações, ao serem lançadas ao fluxo da vida - o artista não sabia quem seria afetado por suas ações-, eram confrontadas com pedestres compelidos a reagir, quase sempre ignorando a origem artística destas propostas. ${ }^{13}$ Não podemos diminuir, porém, a importância que o artista lhe dava aos pedestres ou acidentais testemunhas das suas situações; o depoimento do artista (registrado na sétima citação deste artigo) ilustram a singularidade da relação. O caos e a indeterminação, características das ações do artista 
luso-brasileiro, também entravam no território do pedestre casual. A relação das ações com o público (mais do que um espectador, tratar-se-ia de um participante involuntário) aceitava toda e qualquer reação deste último, sendo que estas intervenções faziam parte de uma obra que se concretizava neste processo de apropriação de noções aparentemente opostas como dentro e fora, autor e público:

\footnotetext{
“(...) esses trabalhos, no momento em que são colocados em praças, ruas, etc., automaticamente tornam-se independentes, sendo que o autor inicial (EU) nada mais tem a fazer no caso, passando esse compromisso para os futuros manipuladores/autores do trabalho, isto é:.........os pedestres, etc. O trabalho não é recuperado, pois foi criado para ser abandonado e seguir sua trajetória de envolvimento psicológico." ${ }^{14}$
}

O valor desta especial noção de público nas ações de Barrio reside na amplitude com que considerou o conceito e as suas possibilidades: Barrio lançava a ação aos domínios da "vida", o controle do trabalho passava ao território das decisões, indecisões e devaneios do pedestre. A não-ação ou qualquer gesto de indiferença eram, por essa razão, uma reação válida e cabível dentro desta idéia mais ampla e livre de espectador, na relação deste com o trabalho artístico. ${ }^{15}$ Dentro das discussões que sobre a participação do público com a obra de arte ocorreram nos anos 60/70 e à luz das ações de Barrio, consideramos que o artista não se posiciona a favor desta participação, o seu trabalho não considera nem mesmo a idéia de público; quando este aparece como tal é de maneira eventual e o que ocorre entre este e os materiais não deve ser necessariamente entendido como "interação". Parece-nos que Barrio toma as precauções necessárias para evitar cair na idílica noção de interação entre público e obra de arte, tão presente na produção artística daqueles anos.

Outra característica desta estratégia de trabalho, denominada por nós como de negação do espetáculo, é que o artista colocou os materiais em diálogo com ambientes/espaços urbanos, deixando de lado os locais destinados normalmente à apresentação artística, isto é, o museu e a galeria. Delineava-se assim uma estratégia de trabalho que deixava ao espectador mais dúvidas do que certezas à respeito da própria natureza artística do projeto: como reconhecer a condição estética de trabalhos que não era apresentados em lugares destinados à exposição artística, realizados com materiais vulgares de vida restrita e que também não eram apresentados a um público, mas lançados e quase que impelidos a se relacionar com o caos do mundo? Ainda mais: como reconhecer o artista, o autor das ações, se ele não se colocava no centro do trabalho? O fato destes trabalhos terem sido desenvolvidos fora dos espaços destinados à divulgação oficial da arte também levanta uma pertinente reivindicação sobre a necessidade de aproximar o trabalho artístico da vida. Quando o artista declara que:

"No me trabalho, a função do processo criativo não se prende mais a uma situação interna, ou seja: o ateliê (ou oficina), como início 
e fim do processo de criação. A idéia pode germinar em qualquer local, no banheiro inclusive, considerado por tanto como local de trabalho." ${ }^{16}$

Depreendemos desta declaração a intenção de repensar os parâmetros que normatizam as relações entre arte e vida. Esta aspiração foi vivida com especial intensidade justamente durante a época das ações do artista (anos 60/70), momento em que o objetivo de reaproximar o espaço da arte do espaço da vida passava pela consciência, por parte do artista, de que o "espaço da vida" era precisamente o lugar rebaixado da cultura de consumo. A aproximação proposta por Barrio entre arte e vida não é ingênua, mas apresenta um lúcido olhar frente a uma sociedade inserida (e ainda mais, tentando se inserir a cada dia um pouco mais) dentro da lógica de compra e venda, consumidora dos produtos - tangiveis e ideológicos - ofertados pela indústria cultural. Dentro desta lógica, aproximar-se do espaço da vida seria justamente trabalhar com produtos "rebaixados" da sociedade e dar a eles um novo sentido. Barrio não trabalha com materiais caros também por esta razão, porque escolher materiais especiais (caros porque destinados à prática de arte) dos que usamos no âmbito da vida, seria reforcar a separação entre arte e vida. Ora, o que pode causar mais estranhamento do que empregar materiais baratos (o papel higiênico, o pão) ou de nenhum valor (as secreções do corpo humano: urina ou escarro) na criação o de um trabalho de arte? E quanto ao local de criação/apresentação (Barrio não diferencia com clareza ambas instâncias), o que significa sair do ateliê, o local de criação artística do artista plástico por excelência, e valorizar espacos públicos ou privados sem nenhum significado especial, como um banheiro ou uma rua qualquer? Talvez a idéia de "invisibilidade" que leva implícita a proposta de trabalhar em lugares como a rua fazia sentido na atmosfera de clandestinidade que imperava nos anos 60/70 no Brasil, mas hoje em dia "trabalhos invisíveis" ${ }^{17}$ podem vir a repensar e contestar algumas características atuais da nossa sociedade, como a sua propensão a espectaculizar qualquer aspecto da vida social ou sua disposição para regrar a vida, planejando,compartimentando e organizando todas as esferas da existência humana. Em todo caso, Barrio apontou uma estratégia de fuga do modelo espectacular através de um trabalho sujo e informe. As ações do artista representam tanto um questionamento ao cotidiano do desprevenido pedestre que se depara com atos que interrompem o fluxo normal do dia-a-dia quanto uma crítica ao sistema de compra e venda do objeto artístico no mercado de arte.

Podemos resumir a proposta artística de Barrio ${ }^{18}$ como a de um trabalho anárquico (de subversão das principais categorias do trabalho artístico, como pudemos ver) que almeja a efemeridade como estratégia de fuga da lógica do museu/galeria, minimizando o seu poder corrosivo no entorno artístico/social. As ações de Barrio, obras efêmeras e processuais, ${ }^{19}$ estabeleciam basicamente um diálogo entre o artista e o material/objeto, assim como entre o primeiro e os vários ambientes em que os materiais eram manipulados. ${ }^{20}$ Salientamos que o diálogo entre Barrio e os vários ambientes significou o abandono do território da imagem para a entrada no campo da experiência; ${ }^{21}$ esta última considerada pelo artista como a própria obra, abandonando assim qualquer aspiração de identificar o trabalho artístico com um objeto estável e perene. ${ }^{22}$ 
O quadro a seguir apenas tenta explicar melhor estas relações, não pretendemos cristalizar um trabalho caracterizado pelo questionamento à idéia mais oficial e estável de obra de arte:

\begin{tabular}{|c|c|c|c|}
\hline Ações & Artista & Público & Ambientes \\
\hline MATERIAIS & $\begin{array}{l}\text { Desenfatizado } \\
\text { durante a ação e ao } \\
\text { serviço dos materiais } \\
\text { O artista se relaciona } \\
\text { com os pedestres e } \\
\text { ambientes através } \\
\text { dos materiais, que } \\
\text { são o centro das } \\
\text { ações. O artista } \\
\text { desempenha o papel } \\
\text { de contra-regra } \\
\text { que irá deflagrar } \\
\text { novas relações entre } \\
\text { estes materiais e } \\
\text { os ambientes e o } \\
\text { público. }\end{array}$ & $\begin{array}{l}\text { Os materiais se } \\
\text { modificam e ganham } \\
\text { vida própria em } \\
\text { contato com os } \\
\text { ambientes (a rua, a } \\
\text { praia, etc), de modo } \\
\text { que ambos são } \\
\text { resignificados a partir } \\
\text { deste contato. }\end{array}$ & $\begin{array}{l}\text { 1)Ele não sabe que o } \\
\text { trabalho é uma ação } \\
\text { artística, mesmo que a } \\
\text { mesma interrompa e } \\
\text { entre em atrito com o seu } \\
\text { cotidiano. } \\
\text { 2) A leitura dos Cadernos/ } \\
\text { livros traz o registro e as } \\
\text { intenções das ações a } \\
\text { posteriori, dando a estas } \\
\text { experi ências uma dimensão } \\
\text { estética mais ampla e } \\
\text { comprensível para o leitor. }\end{array}$ \\
\hline
\end{tabular}

Por outra parte, e a partir de um estudo sobre movimentos artísticos com os que percebeu um alto grau de afinidade com as suas próprias buscas (principalmente os formalistas russos e os simbolistas), sobretudo no que diz respeito à uma recusa do realismo, Kantor se aproximou do evento cênico - efêmero por excelência. Esta aproximação ocorreu primeiro pelo viés do happening e posteriormente a partir da realização de montagens teatrais cujo ponto de partida não seriam somente as suas memórias pessoais, mas a contrução de uma realidade artística paralela à realidade cotidiana, no seu constante propósito em revelar e desestabilizar os mecanismos hegemônicos de representação.

\section{A ação como espetáculo}

Tadeusz Kantor realizou um trabalho teatral que, ao explorar aspectos ligados à representação, desembocou em encenações com um viés espetacular. Realizou investigações visando descobrir mecanismos questionadores do ilusionismo realista e do formalismo. $\mathrm{O}$ espetáculo teatral - a forma de representação teatral por excelência - é a atmosfera propícia para o artista elaborar e experimentar idéias à respeito da representação como evento vivido pelo espectador no aqui/agora. A seguir, passaremos a discutir algumas características importantes no trabalho teatral do artista polonês, dando especial ênfase à noção de ação e ao trabalho desenvolvido com o ator e com o objeto.

Kantor apontou um caminho singular ${ }^{23}$ na construção de um modelo representacional em constante mutação e, por isso mesmo, impossível de ser apreendido sob a forma de um método. A ação no teatro de Kantor se opõe ao previsível encadeamento lógico (ilustração de 
uma fábula contada por um texto) da convenção naturalista. ${ }^{24}$ Sobre a relação entre texto e cena, ele defendeu a autonomia de ambos os elementos, não submetendo nenhum dos dois ao domínio do outro. No entanto, o que Kantor mais defende é a autonomia de uma cena ocidental perante um elemento - o texto - que tradicionalmente norteou o processo de criação teatral, assim como qualquer escolha da encenação. E é, por essa razão, que ele se posiciona tanto contra um naturalismo obediente ao texto quanto contra qualquer solução estilizada que não surja como resultado de uma absoluta "necessidade formal superior" 25 do próprio trabalho. A realização de uma experiência cênica autônoma do texto - mas não alheia e ele - concretizou o objetivo de trabalhar contra uma das convenções mais sedimentadas dentro da tradição teatral em Ocidente, isto é, a dependência da cena ao texto. Esta experiência de autonomia perante o texto foi uma tentativa de retirar deste último a sua condição de elemento deflagrador do processo teatral. Se bem Kantor não questionava propriamente a relação com o texto, ele recusava relações previsíveis, lógicas ou analógicas entre este e a cena. Evidentemente, o naturalismo e o seu cuidado em ilustrar a fábula do texto dramático, tornaram-se alvos frequentes das críticas do artista. Tal relação entre texto e cena limitava as possibilidades desta última, ao passo que empobrecia o trabalho expressivo do ator.

"La “acción" en el viejo teatro naturalista está ligada al encadenamiento de los acontecimientos acumulados en el texto dramático. El elemento teatral "acción” y el trabajo del actor siguen vías estrechas" 26 encenador polonês propõe, como caminho alternativo ao desgaste do dispositivo naturalista, a possibilidade de "ficarmos presos pela ação cênica pura, o elemento teatral por excelência”. O diretor não rejeita o texto, mas demanda o resgate e autonomia da ação cênica perante o tradicional domínio do texto. É instigante (e não deixa de ser sinal da necessidade de o teatro sair da sua especificidade para procurar a sua urgente reciclagem em outras áreas do conhecimento humano) atentarmos para o fato de ser precisamente um artista plástico quem sugere a redescoberta da materialidade cênica do evento teatral, apontada como a grande estratégia de resignificação da ação. Kantor associa a maneira convencional com que entendemos a ação teatral (o encadeamento lógico dos fatos) com uma percepção muito rasteira de olhar para o cotidiano, e que transferimos à relação com os fenômenos artísticos. Para ele, temos que "desarmar o texto e os acontecimentos que o duplicam": se esta atitude parece inviável sob o ponto de vista da vivência cotidiana é porque o problema será resolvido apenas no âmbito da arte, espaço em que a incoerência - ou melhor, a própria lógica do trabalho de arte - pode surgir livremente.

Kantor observou o uso das técnicas tradicionais de enredo na tragédia grega, que expunham historicamente a vida humana como motor de paixões, heroísmos, conflitos e reações violentas. Esta maneira de refletir a existência humana significou, nos seus primórdios, a expansão do homem e do esforço trágico em direção à transcendência da dimensão e do destino humanos. Segundo Kantor, fazia sentido que fosse assim na época da formação e consolidação da tragédia grega. No entanto, com o passar do tempo esta estratégia limitouse a uma forma espetacular que precisava cada vez de mais e mais elementos chamativos e de formas inovadoramente convincentes para garantir uma eficácia que havia esvaziado os seus propósitos iniciais - provocar uma reflexão sobre a existência humana e sobre o 
lugar do homem no mundo. $\mathrm{O}$ achado tornou-se uma fórmula, o saudável espanto que a representação trágica provocava no homem daquele tempo se transformou numa técnica domesticada demais para oferecer ao público alguma reflexão provocadora sobre a realidade. Por essa razão, Kantor propõe um modelo de ação cênica quase que oposto ao da fábula naturalista - herdeira do modelo trágico - que exacerba as paixões humanas: Enquanto que as técnicas acima citadas se centram quase que exclusivamente na exposição dos aspectos mais intensos e passionais da vida humana, Kantor propõe:

“(...) reorientar la acción dramática, dirigirla por debajo del tren normal de vida, a través de la relajación de los lazos biológicos, psicológicos, semánticos, por medio de la pérdida de energía y expresión, por un "enfriamiento" de la temperatura que llega hastal el vacío - ése es el processo de desilusión y la única posibilidad de reencontrar lo real."

O reencontro com o real, apontado por Kantor, diz respeito de uma realidade freqüentemente apagada e dissimulada nos atos e energias cotidianos da vivencia humana. Este reencontro com o real não deve ser confundido com darmos à ação cênica uma equivalência semelhante à da "imitação" mais realista da ação cotidiana. Segundo ele, a cena teatral deve ser autônoma tanto do texto quanto da realidade. Por essa razão, Kantor propõe a abordagem de uma realidade diluída. Diluição entendida como distorção e esvaziamento dos acontecimentos da vida. Na forma como o artista descreve a obtenção desta "realidade diluída", o leitor dos seus manifestos se depara com conceitos que fazem parte de uma mesma família semântica: aniquilação, anulação, diluição: modos de corporificar um aspecto bastante singular de reencontrar (e não repetir mimeticamente) tanto as próprias memórias quanto aspectos menos valorizados da realidade.

Uma das chaves que podemos usar para lermos o pensamento de Kantor é a exacerbação dos procedimentos criativos do ator. Enquanto o ator naturalista constrói personagens dentro de uma medida equivalente à vivência cotidiana, o ator de Kantor não cria mecanismos de identificação com a sua personagem em cada montagem. Na Companhia Cricot 2 não havia atores principais nem papéis fixos para cada ator, ${ }^{28}$ quem possuía a mesma importância que os outros elementos da cena, fato que evidente na organização cênica das montagens. Isto não significava que o ator para Kantor desempenhasse um papel menor; o que estava em jogo era uma dinâmica criativa não comprometida com a tradução de um texto para a linguagem cênica: o diretor dava a todos os elementos da cena uma importância equivalente. $\mathrm{O}$ ator da Companhia Cricot 2 tinha uma participação decisiva no processo criativo, tratava-se, porém, de uma participação diferente da habitual. Já que não se tratava aqui de construir uma personagem sob moldes mais conhecidos (um texto pré-existente), Kantor desenvolveu um processo criativo ancorado nas suas memórias, que ao serem representadas por atores que não viveram essas lembranças, criavam um atrito entre a dimensão (ficcional) das memórias do diretor e a esfera (material) dos atores. A participação dos atores no espaço de memória de Kantor mudava o tempo todo as relações que ocorriam neste espaço. $\mathrm{O}$ acaso e a sorte eram 
elementos usados por Kantor para contestar o pensamento racionalista. Entende-se porque não havia lugar aqui para primeiros atores. Na linha de Meyerhold e Craig, Kantor propõe, através da particular estética dos seus trabalhos, uma nova ética para o ator:

"En esta vía sin concesiones, el actor debe ofrecer su ridículo, su despojamiento, su dignidad misma, aparecer desarmado, fuera de la protección de máscaras falaces” ${ }^{29}$

É possível enxergamos afinidades, neste aspecto, entre as propostas artísticas de Barrio e Kantor. Ambos artistas lidam com o ego do artista em exposição (seja este um ator ou não) de forma que a sua figura não ocupe necessariamente o lugar central do trabalho, mas em função dos outros elementos em jogo (nas ações de Barrio em função dos materiais; no caso de Kantor a partir da articulação entre os diversos elementos da encenação) Esta observação pode trazer ao ator uma compreensão mais ampla do seu papel em cena: entender que ele não é necessariamente a priori a figura principal da ação teatral.

$\mathrm{O}$ ator de Kantor utiliza procedimentos que entram em choque com essas convenções teatrais. Por essa razão, o trabalho do ator com as emoções excedia o viés estritamente psicológico, na tentativa de estabelecer um diálogo mais integral com a realidade empírica, distante das convenções de uma cena pouco interessada na busca de novas soluções representacionais. Como é sabido, o ator de Kantor não representava uma personagem dentro dos moldes convencionais, mas criava figuras estranhas e não isentas de humor ou sarcasmo, utilizando recursos que distorciam qualquer alusão à realidade cotidiana: o exagero, a repetição, movimentos sem um sentido lógico ou emissão de sons sem causalidade.

Dentro deste pensamento, parece-nos coerente descobrir em Kantor uma maneira também empírica de lidar com a ação cênica, através de conceitos vindos da observação dos movimentos: a contração ou contenção.

"À uma atividade confortável e segura de si mesma, aprovada e solidamente construída por todos os lados, (...) opus obstinadamente fenômenos e assuntos que estão além dessas regiões e que possuem a tendência contrária, a (tendência) de se contrair. Esse termo, fraco desde o ponto de vista da vida, é capaz, na arte, de acarretar conseqüências inesperadas. A formação "em expansão", exuberante, pictórica, contrai-se até se tornar um estreito "retalho". Para mim, naturalmente, não se tratava de substituíla pela ascesis e a economia em nome do funcionalismo e da construção. Era o contrário disso! Essa "exuberância” e esse "conforto", tão sedutores na sua aparência, pareceram-me suspeitos, como se mascarassem um completo desaparecimento do poder de ação. Este estreito retalho de vida, que se contraía e era "apenas visivel", tinha todas as possibilidades de reforçar a tensão interior, a poesia e pelo menos um pouco de humor". ${ }^{30}$

Kantor se vale de um elemento observado nos processos naturais, para utilizá-lo na 
via contrária. Se a expansão é o movimento normal na maneira de uma ação cotidiana ser executada pelos seres vivos, Kantor aplica à obra artística a inversão deste modo de operar, criando um estranhamento entre a obra e o público. Ele detecta uma potência interior na ação que opera pelo princípio do esvaziamento, por esta razão propõe a exploração de estados ligados a esta noção, tais como:

"Apatia, melancolia, embrutecimento, esgotamento, amnésia, associações
desorganizadas, depressão profunda, falta de reação, desânimo, vida
vegetativa, distração, aborrecimento, excitação, completa impotência,
lamentação, infantilismo, esclerose, esquizofrenia, delírios maníacos, (...)
sadismo" 31

Este princípio dá ao teatro de Kantor novos significados estéticos e humanos, que contestam a aparente coerência de causa e efeito da ação realista. Parece-nos importante, a esse respeito, a reflexão que tanto Kantor quanto Barrio trazem a respeito de um estado atoral intencionalmente "desdramatizado", um recurso que nos ajuda a enxergar a materilidade da cena.

Vemos que o que está em jogo nesta maneira de entender e trabalhar com a ação se relaciona com os seguintes aspectos:

A ação como elemento independente do texto, isto é, a ação como elemento de essência teatral (fenômeno cênico)

A ação como elemento independente da realidade cotidiana. Esta independência se manifesta no fato da mesma usar princípios autônomos com relação aos observados na realidade cotidiana.

Por outro lado, vemos que Kantor tenta dissociar a ação teatral do pensamento de causaefeito, muito associado à tarefa de narrar uma fábula. O que acontece quando a ação teatral se centra na ilustração de uma fábula? Com variações de intensidade nas múltiplas propostas do teatro contemporâneo, podemos verificar que a uma maior atenção dispensada à narrativa da fábula corresponde uma desvalorização da materialidade da cena. Os acidentes, acasos e outras maneiras alternativas à lógica causal (na narrativa da história e na conformação dos elementos da cena), oferecem ao público a possibilidade de conversar com a fábula da própria materialidade cênica e não apenas com uma fábula anterior e alheia à mesma.

A "espetacularidade" das encenações de Kantor encontra-se em grande medida ancorada nas lacunas existentes entre texto e cena. A cena que não traduz cinematograficamente o texto mas o "estilhaça", como o moedor de carne faz, mergulha na materialidade cênica para construir um discurso e uma lógica que não descansam mais no texto, mesmo se utilizando dele ele.

"A theatrical performance is, for Kantor, not a realization of the text but 
(to borrow his own term) a "text-mincer" that cuts across or runs parallel to (but separate from) the world of the text (the world of the dead)"32

Outra manifestação da não subordinação da cena a uma narrativa significou, no teatro de Kantor, no resgate e valorização de elementos aparentemente banais e de utilidade corriqueira. ${ }^{33}$ Elementos ordinários como simples embalagens (sacos e caixas) foram redimensionados no Teatro Cricot 2. Se na vida cotidiana as embalagens são apenas objetos que guardam e protegem coisas de valor, para Kantor as embalagens passam a ocupar um lugar de destaque, talvez pela possibilidade de resgate (da memória, de uma realidade esquecida) que estas oferecem. Sobre as possibilidades expressivas que as embalagens guardariam, Kantor destaca a condição misteriosa da sua "completa gratuidade sobretudo quando somos cientes de que as mesmas se desenvolvem com propósitos que apenas dependem do acaso" e não de uma lógica pragmática ou finalista. Ações potenciais da embalagem que Kantor aponta: dobrar, amarrar e marcar.

\footnotetext{
"Let us discuss some of the stages of this ritual: folding, whose complicated strategies requiring some mysterious initiation and a surprising end effect bring to mind magic and a child 's play; tying up, the knowledge of various types of knots touches almost on a domain of sacred knowledge; sealing, always full of dignity and complete concentration; this gradation of actions, this adding of surprising effects, as well as human need and desire to store, isolate, hide, transfer, becomes an almost autonomous process. This is our chance." ${ }^{34}$
}

A estas possibilidades físicas do objeto embalagem, Kantor acrescenta também possibilidades de ordem emocional, ampliando o valor do objeto e da relação entre este e o ator:

"We must not overlook its emotional possibilities. There are many such possibilities inside it: promise, hope, premonition, temptation, desire for the unknown and for the mistery." 35

No entanto, não se trata só de “possibilidades emocionais”, mas também de valores e sentidos importantes para um imaginário fascinado pelo mistério do desconhecido que guarda um objeto aparentemente banal. Podemos ver como Kantor e Barrio através de estratégias diversas, voltam a sua atenção para aspectos (objetos ou materiais) fortuitos e vulgares da realidade, objetos que dentro do pensamento pragmático da sociedade de consumo possuem um valor apenas funcional, mas que em mãos destes artistas ganham uma dimensão que ultrapassa o seu uso comum e o status de mercadoria. Por outro lado, e voltando ao ator kantoriano, não caberia perguntar se esta figura - tão próxima do boneco no tratamento que ganha em cena - não assume a condição de objeto ou de mercadoria?

Diante da complexidade do momento histórico que o polonês viveu, ele optou por 
investigar e extrair da realidade os seus aspectos mais baixos, exteriores e triviais. Esta forma de observar e trabalhar com o "real" imprimiu aos espetáculos de Kantor a característica de uma forma espetacular associada à realidade "de mais baixo grau". A escolha dos materiais e objetos, feita por Kantor e Barrio, revela que ambos prestaram especial atenção a aspectos de uma realidade geralmente desprezada e marginalizada. A noção de "realidade do mais baixo grau” poderia ser ligada à idéia de imanência, imanência que em Kantor significa, como vimos, a valorização da materialidade cênica a partir de um trabalho espetacular e em Barrio a exploração do caráter indicial da obra.

Kantor e Barrio utilizam a ação como estratégia artística capaz de estabelecer um diálogo mais autônomo e dinâmico com a realidade. As ações de Barrio são híbridos que misturam "o comportamento" apresentado por determinados materiais em ambientes da realidade cotidiana; tendo por um lado a presença do artista como "contra-regra" ou regentemanipulador dos referidos materiais e por outro a presença dos pedestres (espectadores incidentais) que se defrontam com situações que interrompem o fluxo cotidiano das suas vidas. Não há uma hierarquização evidente no sentido de podermos determinar qual elemento destes trabalhos tem a prioridade perante os outros; eis o motivo do hibridismo destes trabalhos: eles acontecem na efemeridade de um projeto artístico que deixa apenas registros e vestígios, mas não uma obra acabada e passível de ser nomeada de "ação". Se em Barrio o hibridismo e o caos são características do seu trabalho de ações, detectamos que o trabalho de Kantor se enquadra mais facilmente dentro da categoria teatral; trata-se, porém, de ações teatrais com propriedades muito ambíguas. Como no trabalho de Barrio, o encenador polonês se opõe à ação lógica e causal, assim como a uma previsível hierarquização dos elementos constitutivos do trabalho artístico. No entanto, e como senhor das suas memórias, Kantor possui um controle maior nos acontecimentos do seu teatro - se comparado com o trabalho de Barrio. Não é casual o fato de ele ser autor dos textos, além de criador dos objetos e figurinos das suas peças; é muito significativo também o fato de Kantor aparecer em cena como Kantor o encenador e detentor das suas lembranças, um território não dominado pela realidade, mas pela re-construção que ele faz deste material assumidamente subjetivo. Kantor é um artista que brinca de ser Deus ao criar as suas próprias regra de realidade artificial; Barrio é o artista anárquico que liberta os materiais orgânicos de uma domesticação secular e os deixa invadir o cotidiano anestesiante de gente que não sabe que aquilo é um trabalho com valores estéticos. A perda de controle é uma busca por atingir níveis de realidade ocultos, esquecidos, reprimidos. Se em Kantor a ação está pautada pela repetição e pela criação como evento artificial (a criação do homem), em Barrio a ação está contaminada por uma espontaneidade que quer se ver longe do peso da tradição e das artes plásticas. Essa "espontaneidade" se refletiria na decisão de abrir mão da autoria do trabalho (o pedestre que se defrontou com as ações de Barrio talvez ignore até agora que se tratava de trabalhos artísticos e que ele interferiu no rumo deles) e no fato de serem trabalhos realizados uma única vez. Barrio desmascara a ilusão de realidade que o ser humano vive numa existência pautada por condicionamentos e lógicas utilitárias que o impedem de explorar as diversas potências do real; já Kantor trabalha a construção de uma ilusão que é autônoma da realidade, a ação cênica em Kantor constrói ilusões (invenções alheias ao cotidiano) tão vigorosas que questionam não só a realidade do 
dia-a-dia, mas toda arte figurativa que pensa a ilusão como "cópia” do real. O raro trânsito entre ilusão, realidade e arte, observado nas obras de Kantor e Barrio, torna estes modelos representacionais um potente questionamento aos mecanismos de representação dominantes e uma incomum crítica ao entendimento de 'realidade' submetido à lógica do capital.

\section{Notas}

1 Uma cena múltiple, descentrada e desterrritorializada, à maneira do mapa de uma estrutura rizomática, que nos permite confrontar dois artistas diversos na sua nacionalidade, época e projetos artísticos: "O mapa é aberto, é conectável em todas as suas dimensões, desmontável, reversível, suscetível de receber modificações constantemente. Ele pode ser rasgado, revertido, adaptar-se a montagens de qualquer natureza, ser preparado por um indivíduo, um grupo, uma formação social (...) Uma das características mais importantes do rizoma talveza seja a de ter sempre múltiplas entradas (...) um mapa tem múltiplas entradas...” in DELEUZE, Gilles. Mil Platos - capitalismo e esquizofrenia Vol. 1. Rio de Janeiro: Ed. 32, 1995. p. 22

${ }^{2}$ A noção de fronteira é apontada por Renato Cohen como a de um “(...) imbrincamento entre campo ficcional e "real", trespassando a fronteira arte/vida, são inúmeros (os exemplos) nos caminhos da avant garde e contracultura (ponto focal dos happenings e performances) (...)”. Essa noção mais ampla de fronteira também pode ser entendida como o apagamento dos limites que delimitam cada um dos campos artísticos. In COHEN, Renato. Work in Progress na Cena Contemporânea São Paulo: Editora Perspectiva, 1998. p. 60.

${ }^{3}$ Artista plástico português (1945-) atualmente radicado no RJ e que ganhou notoriedade a partir de finais da década de 60, de quando a realização da suas ações.

${ }^{4}$ Em repetidas ocasiões o artista tem marcado distancia da performance. No entanto, nao podemos deixar de reconhecer as visíveis relações entre esta e sua as ações, mesmo que estas últimas apresentem características que as situam na fronteira do real ou do "anti-estético". A seguir, citamos o artista português: "Eu vi-me no centro de algumas dessas ações, quando na verdade o meu intuito não era aparecer fisicamente (...) de uma certa maneira me envolvi fisicamente com esse trabalho (...) a minha idéia de trabalhar fisicamente era ter essa relação com o corpo, sentir o corpo, viver de outra maneira, tentar dizer com o corpo (...) esse relacionamento eu não quis que resbalasse muito para o teatro (...) nunca fiz como outros, que a crítica em vez de analisar cada ponto, coloca tudo no mesmo saco e diz 'performance' e acabou." Ver BARRIGA, Merle Ivone. "Entrevista com Artur Barrio" in: As Ações de Artur Barrio: Um modelo não representacional para o ator contemporâneo. Mestrado defendido na ECA-USP, Sao Paulo. 2006.

${ }^{5}$ BARRIO, Artur. "Manifesto". in CANONGIA, Ligia (Org) Artur Barrio. Rio de Janeiro: Modo, 2002. P. 145.

${ }^{6}$ Proponho aqui um entendimento mais amplo deste conceito, uma vez que o que denominamos de "efeito realista" não seria um estilo estável e imutável mas uma inecessante búsqueda que se caracteriza por aproximar o trabalho artístico da vida humana. Obviamente que o efeito realista varia de acordo com a época, o local e o pensamento de cada sociedade.

${ }^{7}$ BARRIO, Artur. "Meu trabalho está ligado auma situação subjetiva/objetiva -:- mente/corpo" in CANONGIA, Ligia (Org) Artur Barrio. Rio de Janeiro: Modo, 2002. p. 146. O negrito é nosso.

${ }^{8}$ Ossos, pão, papel higiênico, entre outros, foram os materiais nada sagrados que Barrio usou na realização de ações que asignava a estes elementos uma estranha e perigosa potência nos ambientes urbanos em que foram lançados.

${ }^{9}$ O gesto não ensaiado nem fixado do artista que se apresenta como suporte dos materiais, estes sim, os verdadeiros “atores” das ações. Por outro lado, é pertinente esclarecermos que esta presença mais espontânea do artista mostrou um registro que evitou cair em atitudes histriônicas.

${ }^{10}$ Na ação P.....H....1969, Barrio lançou ao mar vários rolos de papel higiênico. O registro fotográfico da ação mostra um artista à vontade e despretenciosamente ao serviço do material que espalhava pelo mar. 
${ }^{11}$ CANONGIA, Ligia. "Barrio Dinamite". in CANONGIA, Ligia. (Org) Ibidem. p. 215.

${ }^{12}$ As relações entre Barrio e as vanguardas históricas (notadamente o surrealismo e o dadaismo) são mais do que evidentes para os comentadores da obra de Barrio. Um dos aspectos em que esta relação se mostra mais contundente é precisamente na intenção de (re)aproximar a arte da vida. A este respeito citamos o depoimento de um artista dadaísta: "O motivo pelo qual, oficialmente, não falávamos de arte, e sim de anti-arte, devia-se ao fato de que, para nós, toda e qualquer arte-como-empresa havia se tornado imprestável. O que buscávamos era um caminho que voltasse a fazer da arte um instrumento conveniente da vida (...) A busca de um conteúdo unia-nos a todos." in RICHTER, Hans. Dada: Arte e Antiarte. São Paulo: Martins Fontes, 1993.p. 60.

${ }^{13}$ Também a categoria de artista foi contestada pelo criador português, ao declarar que: "O trabalho tem vida própria porque ele é o todos nós, porque é a nossa realidade do dia-a-dia, e é nesse ponto que abro mão do meu enquadramento como "artista", porque não sou mais, nem especificamente necessito de qualquer outro rótulo..." BARRIO, Artur. Do manifesto "Lama/Carne Esgoto" in CANONGIA, Ligia (Org) Ibidem. p. 146

${ }^{14}$ CANONGIA, Ligia (Org) Ibidem. p. 142.

${ }^{15}$ Neste sentido, a nossa opção pela uso do termo "ação" não desestima a celebração que o mesmo Barrio faz da inação - o não fazer. Sendo assim, a idéia de ação aquí problematizada não estaria necessariamente ligada a uma atividade finalista, produtiva ou causal, mas a estratégias de atuação epidérmicas e empíricas. No caso específico do artista português, que nomeou esta fase do seu trabalho como "ações", vemos a referência às ações de guerrilha, praticadas justamente entre os anos 60 e 70.

${ }^{16}$ BARRIO, Artur. "Meu trabalho está ligado auma situação subjetiva/objetiva -:- mente/corpo" in CANONGIA, Ligia (Org) Ibidem. p. 146.

${ }^{17}$ Não é a nossa intenção relacionar trabalhos como os de Barrio com o "teatro invisivel". Consideramos que, nos seus propósitos e nas estratégias empregadas, se trataria de dois modos específicos de dialogar com a realidade e de produzir trabalhos artísticos.

${ }^{18}$ Artur Barrio é o autor de ações tais como "Trouxas ensangüentadas" e "4 dias, 4 noites", realizadas em finais dos anos 60 e começo dos 70 .

${ }^{19}$ Dada a origem orgânico-perecivel dos materiais com que Barrio trabalhou nas suas ações, o único vestígio destes trabalhos foi o seu registro. A eficácia destas obras dependia justamente da sua transitoriedade; a representação era colocada em xeque em trabalhos fadados a desaparecer.

${ }^{20}$ Podemos mencionar como ambientes o espaço físico (ruas, paisagens naturais, condições climáticas), psicosocial (a interação que as pessoas tiveram com essas situações), subjetivo (envolvendo aqui tanto a subjetividade do artista quanto a das outras pessoas envolvidas com as ações), político (a ditadura militar) e estético (as motivações estéticas e a crítica freqüente que estes trabalhos lançaram à arte instituída)

${ }^{21}$ A respeito da passagem da obra como imagem para o trabalho artístico como experiência, ocorrida a partir das vanguardas históricas de início do século XX, recomendamos a leitura de GOLDBERG, Roselee. Performance: Live art since the 60's. Singapore: C.S. Graphics, 1998.

${ }^{22}$ Sobre os trabalhos da Arte Povera (que significa "tecnologicamente pobre em um mundo tecnologicamente rico"), cujas afinidades com Barrio são evidentes, Argan pergunta até que ponto a negação do objeto em favor da experiência (segundo ele, algo que não pode ser historicizado) não significaria privar "à sociedade opulenta de algo que ela quer e precisa.", isto é, o objeto artístico. Por conta da intencionalidade artística de Barrio, consideramos que a discussão não deve ser desviada do debate estético. Barrio opera neste âmbito, se utilizando de procedimentos que levantam questões éticas, mas sobretudo estéticas. Negar a essencialidade artística das ações de Barrio em função da efemeridade das mesmas significaria apagar a importância de uma linhagem de trabalhos que, através da experiência, encontrou um caminho de investigação e questionamento dos valores mercantis da arte moderna e contemporânea. in ARGAN, G.C. El Arte Moderno 1770-1970 Valencia: Fernando Torres. Editor, 1977. p. 687. Tradução livre ao português.

${ }^{23}$ A utilização das próprias memórias, não como recurso nostálgico, mas como construção e destruição permanente das mesmas, a modo de afirmar o ato artístico criativo como criação de uma realidade autônoma.

${ }^{24}$ No "Manifesto do teatro zero" Kantor expõe os problemas da ação no teatro naturalista. No mesmo texto, o artista 
polonês resume o seu descontentamento com este teatro ao associar o "figurativo" no teatro ao encadeamento dos acontecimentos reais e vividos, isto é, à fábula.

${ }^{25}$ KANTOR, Tadeusz."Manifiesto del Teatro Cero". El Teatro de la Muerte Selección y presentación de Denis Bablet. Buenos Aires: Ediciones de la Flor, 1984. p. 33. Neste texto Kantor fala da necessidade das escolhas artísticas serem guiadas por "una necesidad formal superior"

26 Tradução livre: "A ação no velho teatro naturalista está associada ao encadeamento dos acontecimentos acumulados no texto dramático. O elemento teatral "ação" e o trabalho do ator trilham vias estreitas." Do "Teatro Autonomo” in KANTOR, Tadeusz. El Teatro de la Muerte Op. Cit. p. 87-88. Todas as traduções feitas pela autora do artigo.

27 Tradução livre: “(...)reorientar a ação dramática, dirigi-la para baixo do curso normal dos acontecimentos, por meio do relaxamento dos laços biológicos, psicológicos, semânticos, através da perda de energia e expressão, de um "esfriamento" da temperatura que chegue até o vazio - eis o processo de desilusão e a única possibilidade de reencontrar o real." In KANTOR, Tadeusz. "Manifiesto del Teatro Cero". in El Teatro de la Muerte op. cit. p. 115 .

28 É pertinente entendermos o ator do teatro de Kantor na sua dimensão mais completa. Muitos deles não eram atores profissionais, mas artistas de outras áreas convidados por Kantor para trabalhar em cena. Por outra parte, alguns deles acompanharam o encenador durante décadas, o que deu à relação artística entre eles uma maior profundidade.

29 Tradução livre: "Nesta vía sem concessões, o ator deve oferecer o seu ridículo, o seu despojamento, a própria dignidade, aparecer desarmado, longe da proteção de máscaras falaces.” KANTOR, Tadeusz. Op. Cit. Pp. 85-86.

${ }^{30}$ KANTOR, Tadeusz. "Manifesto do teatro zero". Ibidem. P. 79

31 KANTOR, Tadeusz. Op. cit. P. 115.

32 Tradução livre: "Uma apresentação teatral é, para Kantor, não a concretização do texto, mas (usando as suas próprias palavras) uma máquina "moedora do texto" que corta ou corre paralelo ao (mas separado de) o mundo do texto (o mundo da morte)" G.M. Hyde: "A new lease of death”, in: KANTOR, Tadeusz. Wielopoe/Wielopole: an exercise in theater Marion Boyars Publishers, 1990. p. 8

${ }^{33}$ Por limitações de espaço optamos por não abordar a importancia fundamental da figura de Kantor em cena e do espaço real e histórico em algumas das suas montagens. Deixamos estes temas para futuros desdobramentos.

34 Tradução livre: Discutamos as fases deste ritual: dobrar, cujas complicadas estratégias necessitam alguma misteriosa iniciação, assim como o efeito final sempre inesperado, sempre surpreendente, participa um pouco da magia e outro pouco do jogo infantil, amarrar, o conhecimento dos vários tipos de nós quase roça o domínio das tradições sagradas, marcar, sempre recheado de dignidade e completa concentração; esta acumulação de operações sucessivas, adicao de efeitos imprevissíveis, como também essa necessidade humana e o nosso desejo de armazenar, isolar, esconder, transferir, torna-se um proceso quase que autônomo. Essa é a nossa sorte. KOBIALKA, Michael (Org) A Journey Through Other Spaces (essays and Manifestos 1944-1990) Edited and translated by Michael Kobialka. California: University of California Press, 1993. p. 79-80.

${ }^{35}$ Tradução livre: Não percamos de vista as possibilidades emocionais da embalagem: Há muitas possibilidades que esta encerra: a promessa, a esperança, as premonições, a tentação, o desejo pelo desconhecido e pelo mistério." in KOBIALKA, Michael (Org)op. cit. p. 80. 